The more the merrier? Understanding how travel frequency shapes willingness to pay

Marta Nieto García ${ }^{\mathrm{a}}$, Pablo A. Muñoz Gallego ${ }^{\mathrm{b}}$, Óscar Gonzalez Benito ${ }^{\mathrm{c}}$

Keywords: willingness to pay, travel frequency, reference price, dynamic pricing, room rates

${ }^{a}$ University of Portsmouth, Faculty of Business and Law, Richmond Building, Portland Street, Portsmouth PO1 3DE. Telf. +44 02392844028

Corresponding author: marta.garcia@port.ac.uk

${ }^{\mathrm{b}}$ Universidad de Salamanca, Instituto Multidisciplinar de Empresa, Edificio FES Campus Unamuno, 37007 Salamanca, Spain. Telf. +34 923294500 (3127)

pmunoz@usal.es

${ }^{\mathrm{c}}$ Universidad de Salamanca, Instituto Multidisciplinar de Empresa, Edificio FES Campus Unamuno, 37007 Salamanca, Spain. Telf. +34 923294500 (3008)

oscargb@usal.es 


\title{
The more the merrier? Understanding how travel frequency shapes willingness to pay
}

\begin{abstract}
Customers' evaluation of hotel prices has received increasing attention in hospitality research. Beyond the specific attributes of the offer, internal norms related to prior experiences affect customers' response to price. Drawing on the behavioral price literature, this study investigates the effect of travel frequency and reference price on the formation of travelers' willingness to pay (WTP) for accommodation.
\end{abstract}

The study presents a novel methodological approach introducing the concept of instantaneous indirect effect. Results offer support for an inverted U-shaped relationship between travel frequency and WTP, mediated by the internal reference price. WTP reaches its peak when the customer has booked an accommodation six times in the past two-year period.

The findings provide clear implications for practitioners. Monitoring customers' travel frequency and integrating it into dynamic pricing models will create a better alignment of room rates with travelers' WTP, which will make revenue management techniques more customer-centric and, ultimately, enhance profitability.

Keywords: willingness to pay, travel frequency, reference price, dynamic pricing, instantaneous indirect effect, room rates 


\section{Introduction}

In the hospitality industry, dynamic pricing has become a key element of revenue management practices (Abrate, Fraquelli, \& Viglia, 2012). Hospitality practitioners agree that these practices are evolving toward the commoditization of the industry, which they are trying to overcome by communicating a clear value proposition to the customer (Wroten, 2018). As a result, hotel revenue management is becoming strategic and customer-centric, with practitioners increasingly using marketing analytics for price discrimination. Recent evidence shows a major shift in the industry from segment-based pricing to individual customer pricing (Kimes, 2017; Noone, Enz \& Glassmire, 2017). In parallel, new solutions for a customer-centric pricing approach are emerging (e.g., Duetto, 2019). Building up on these insights and with the purpose of guiding future research in hotel pricing, this study intends to broaden the current understanding of the factors that shape customer willingness to pay (WTP).

Individual perceptions and internal norms underlie how customers respond to price information (Cheng \& Monroe, 2013). In the hospitality domain, the traveler's prior knowledge of the service plays a central role (Gursoy \& McCleary, 2004a). Drawing on the behavioral price literature, this study investigates the effect of travel frequency on leisure travelers' WTP. While previous literature has investigated the role of reference prices in customer evaluation of hotel prices (e.g., Choi \& Mattila, 2017; Viglia, Mauri, \& Carricano, 2016), past research has fallen short of analyzing how different customer characteristics affect the formation of reference prices and WTP (Choi, Joe, \& Mattila, 2017; Denizci Guillet \& Mohammed, 2015).

Theoretically, the results of this research provide a clear understanding of the influence of travel frequency on customers' WTP for holiday accommodation. First, the study provides 
empirical evidence of a mediating effect of internal reference price (IRP) on the relationship between travel frequency and WTP. Travel frequency positively affects IRP, which in turn affects customers' WTP. Second, by embracing the concept of consumer habituation (Wathieu, 2004), this study shows that leisure travelers experience habituation when their travel frequency reaches a certain level. The findings reveal that as travel frequency increases, travelers are willing to pay more for the accommodation, but this effect reaches its peak at six times over the past two-year period. Once travelers get to the habituation phase, increasing travel frequency has a negative effect on travelers' WTP.

From a managerial perspective, these results present relevant implications in terms of hotel revenue management $(\mathrm{RM})$. Traditional segmentation techniques are becoming less effective, and RM professionals are expanding their practice to focus on each customer's WTP (Noone, et al., 2017). Customer relationship management (CRM) systems capture, store, and analyze information about each customer's previous transactions. This information should be tightly linked to RM systems. Adopting a more customer-centric approach that integrates customers' travel patterns into pricing strategies would allow hoteliers and online travel agents to optimize revenues. Last, personalized offers may help practitioners counteract the habituation effect and enhance customer profitability.

\section{Theoretical background}

\subsection{Research on willingness to pay (WTP)}

Customers' WTP refers to the maximum price the customer will agree to pay for a given quantity of a product (Cameron \& James, 1987). Research on WTP has traditionally adopted a product-centric perspective. One major area of marketing research on WTP has investigated the effect of different attributes of the product on customers' WTP, such as the product's country of origin, the product life, the retail channel, or marketing campaigns (e.g., Chatterjee 
\& Kumar, 2017; Koschate-Fischer, Diamantopoulos, \& Oldenkotte, 2012; Koschate-Fischer, Stefan, \& Hoyer, 2012). Going beyond the product-centric stream, other studies have focused on environmental anchors affecting WTP, such as incidental prices of related and non-related products (e.g., Adaval \& Wyer, 2011; Dogerlioglu-Demir \& Kocas, 2015; Nunes \& Boatwright, 2004). Finally, customer WTP has been investigated in the field of behavioral price research. This research stream posits that customers have individual, internal norms against which they judge prices (Cheng \& Monroe, 2013). Behavioral characteristics specific to the customer are at the core of price information processing (Moon, Russell, \& Duvvuri, 2006). The concept of reference price has been widely examined in this field (Kalyanaram \& Winer, 1995); however, the vast majority of studies on reference price have focused on frequently purchased goods and there is limited research on the formation of reference prices for services (Mazumdar, Raj, \& Sinha, 2005).

Travel and accommodation services often entail high price levels, which increases the importance of price in the decision-making process (Monroe, 2002; Nagle \& Holden, 2002). In the case of hotels, room prices are crucial for customers' choices (Choi \& Mattila, 2006; Pan, Zhang, \& Law, 2013). Similar to durable goods, these services are typically associated with high levels of consumer involvement, motivating increased attention to price information. Therefore, the impact of purchase frequency on consumer price evaluations is likely to be strong (Estelami \& De Maeyer, 2004). Finally, the information search process for hospitality services is unique in that travelers experience high information asymmetry before their purchase, thereby increasing the salience of their prior knowledge (Gursoy \& McCleary, 2004a, 2004b; Teare, 1992).

[Insert Table 1 around here] 
Research on customers' WTP in the hospitality domain has mainly focused on specific product attributes (e.g., green certification, luxury amenities; see Table 1), with only a few studies offering a more customer-centric analysis of travelers' WTP for accommodation (e.g., Masiero, Heo, \& Pan, 2015; Masiero, Nicolau, \& Law, 2015; Monty \& Skidmore, 2003). Most of these works overlook the role of travelers' past experiences and none of them analyzes the direct effect of travel frequency on WTP. Therefore, there are unanswered questions relating to the effect of travelers' prior knowledge on their WTP.

\subsection{Prior knowledge and price acceptability}

Customers' prior knowledge plays a key role in the decision-making process (Bettman, 1979). Specifically, prior knowledge has a strong impact on the information search stage (Bettman \& Park, 1980; Fodness \& Murray, 1998; Johnson \& Russo, 1984). Prior knowledge also facilitates customers' information processing (Gruber, Schlegelmilch, \& Houston, 2014; Park, Mothersbaugh, \& Feick, 1994). Customers with high product category knowledge find it easy to evaluate a product's attributes and utility (Ratchford, 2001). From a psychological standpoint, a number of studies suggest that customers' prior knowledge has an influence on price acceptability (e.g., Cordell, 1997; Rao \& Sieben, 1992) and customers' WTP (Lichtenstein, Bloch, \& Black, 1988). A customer's product category knowledge affects the customer's acceptable price range (Rao \& Sieben, 1992). The size of the price range that delineates the customer's price tolerance depends on his or her involvement with the product (Herrmann, Huber, Sivakumar, \& Wricke, 2004). Researchers generally agree that the greater the degree of product category knowledge, the higher the price tolerance (Cummings \& Ostrom, 1982; Divine, 1995; Herrmann et al., 2004; Rao \& Sieben, 1992).

\section{Hypotheses development}




\subsection{Influence of travel frequency on customer WTP}

Familiarity with the product is a major component of customers' prior knowledge (Cordell, 1997; Park et al., 1994). The number of product-related experiences accumulated by the customer represents their familiarity with the specific product (Alba \& Hutchinson, 1987). Therefore, the level of familiarity with the product category increases with previous purchase experiences (Monroe \& Lee, 1999). Empirical evidence suggests that product category familiarity determines customer preferences (Coupey, Irwin, \& Payne, 1998). Specifically, product category familiarity exerts a strong influence on price perceptions (Biswas, 1992; Biswas \& Blair, 1991).

In this study, travel frequency serves as a proxy for product category familiarity. Because frequent travelers have more product category knowledge, they will exhibit higher price tolerance (Cummings \& Ostrom, 1982; Divine, 1995; Rao \& Sieben, 1992). Following this argument, one would predict a positive relationship between travel frequency and WTP. However, there is evidence that beyond a certain level of past consumption experience with the product, WTP decreases due to customer habituation (Wathieu, 2004). Habituation refers to a decreased response to repeated stimulation (Groves \& Thompson, 1970). Whereas inexperienced customers' WTP increases with repeated purchases, when the experience becomes habitual, their WTP starts to decrease (Wathieu, 2004). In light of this, previous studies suggest that WTP is greater for a moderate level of product familiarity or purchase frequency (Baucells \& Sarin, 2010; Kim \& Rossi, 1994; Wathieu, 2004). Rao and Sieben (1992) also argue that beyond a certain point on the prior knowledge continuum, the highest price customers are willing to pay will not continue to increase. Similarly, research has shown a nonlinear effect of satisfaction on WTP (Homburg, Koschate, \& Hoyer, 2005). 
Building on these arguments, this study proposes that travel frequency, as an indicator of customers' familiarity with the service, has a positive impact on customers' WTP up to a point, after which the impact of travel frequency on customers' WTP decreases. More formally:

H1. The relationship between travel frequency and customers' WTP follows an inverted Ushaped function.

\subsection{The mediating effect of internal reference price (IRP)}

Reference price is a central construct in the behavioral price literature (Kalyanaram \& Winer, 1995; Rajendran \& Tellis, 1994). Reference price refers to the standard to which an individual compares the purchase price of an offering (Monroe, 1973; Winer, 1986). Over the years, scholars have proposed various ways to operationalize this construct. Reference prices can be memory-based, if a previously encountered price serves to predict the reference price, or stimulus-based, if customers rely on information available in the purchase environment (Briesch, Krishnamurthi, Mazumdar, \& Raj, 1997). For instance, Gabor and Granger (1961, p. 176) consider the reference price as memory-based, being the reflection of "the previous price paid". However, reference prices are product-specific; thus these operationalizations may not be valid across different goods or services. Contextual, psychological, and physiological factors also play a role in shaping the reference price. As Cheng and Monroe (2013, p. 156) summarize in their appraisal of behavioral price research:

A reference price is a dynamic internal price to which an individual compares the offered price of a product of service. It may be an internal price the buyer may remember from a previous purchase, an expected price, a belief about what would be a fair price for the product in the same market area, or perhaps some vague notion of what the product might be worth. 
In this study, we consider the IRP as a memory-based reference price that reflects the prices that customers have encountered on past purchase occasions (Rajendran \& Tellis, 1994). This operationalization seems to be appropriate given the intrinsic characteristics of the service. Booking accommodation is a high-involvement purchase decision (Torres, Singh, \& Robertson-Ring, 2015), and thus customers often spend considerable time searching for product information to make the right choice (Clarke \& Belk, 1979). It is therefore likely that the customer will recall the price paid in future bookings.

Mazumdar et al. (2005) provide an integrative framework of prior research on the formation, retrieval, and influence of reference prices. Offering a comprehensive summary of reference price research, the study also identifies unresolved issues and proposes an agenda for future research. Specifically, the authors highlight that most of the studies on reference price have focused on frequently purchased goods. Therefore, there is a need for a deeper understanding of the role of reference prices in service purchase decisions.

In the hospitality domain, recent studies have shown the relevant role of IRP in price evaluation (Choi \& Mattila, 2017; Choi et al., 2017; Viglia \& Abrate, 2014). Research is still limited in terms of understanding how psychological traits shape travelers' WTP. In an attempt to address this gap, the present study investigates the mediating effect of IRP on the relationship between travel frequency and WTP.

\subsubsection{Impact of travel frequency on customer IRP}

Frequent travelers rely on internal information, as opposed to external information, when searching for tourist accommodation (Fodness \& Murray, 1998). Because frequent travelers are more aware of the details of their purchases, they can more easily recall prior purchase information from memory (Mazumdar \& Monroe, 1990; Monroe \& Lee, 1999). Therefore, travel frequency will increase internal information about the service. 
Reference price effects tend to occur when customers have more experience with the productcategory (Kalyanaram \& Winer, 1995; Rajendran \& Tellis, 1994). Customers form price expectations considering their own prior experiences with the product (Briesch et al., 1997; Mazumdar et al., 2005). In hospitality services, frequent buyers rely more on reference prices rather than contextual cues to evaluate newly encountered prices (Karande \& Magnini, 2011). Stemming from our preceding discussion on prior experience and price acceptability, the size of the price range that delineates the customer's price tolerance depends on his or her involvement with the product (Herrmann et al., 2004). Specifically, the greater the degree of product involvement, the higher the price tolerance (Cummings \& Ostrom, 1982; Divine, 1995; Herrmann et al., 2004; Rao \& Sieben, 1992). Assuming that high travel frequency entails high involvement with the product, customers with higher travel frequency (higher product involvement) should tolerate higher prices. As a result, they will be more inclined to purchase high price offerings. According to adaptation level theory (Helson, 1964), customers' reference prices — or adaptation levels — are influenced by the stimulus the individual is directly responding to (i.e., the newly encountered price). Therefore, the newly encountered price will be compared to the reference price and will adjust the reference price. Prices above or below the reference price will move the adaptation level in their direction; when the newly encountered price is higher than the reference price, it will shift the reference price upward (Cheng \& Monroe, 2013). Thus, frequent exposure to high prices is likely to increase customers' IRP. A positive relationship is therefore expected between travel frequency and customers' IRP. More formally:

H2. Travel frequency positively affects IRP. 


\subsubsection{Impact of IRP on customer WTP}

In line with adaptation level theory, customers' reactions to price will be affected by their reference price (Helson, 1964). The acceptability of a price is judged by comparison to the adaptation level—i.e., the reference price for the product category (Mazumdar et al., 2005). Customers' memory of past prices serves as an anchor to determine their WTP (Hofstetter, Miller, Krohmer, \& Zhang, 2013). Every newly encountered price will be judged against the adaptation level. If the price falls outside the acceptable range, it will move the adaptation level in that direction, thereby changing the customer's perception of other prices. In light of these arguments, the higher the reference price, the higher the adaptation level against which the newly encountered price will be compared. This results in higher WTP for the specific product.

Therefore, IRP should have a positive impact on customers' WTP. A question arises, however, as to whether the impact of IRP on WTP might change across different levels of IRP. As IRP increases, it may reach the threshold beyond which new prices will not be considered acceptable. When the newly encountered price is too high, a contrast effect will take place and the customer will not be willing to accept that price (Sherif \& Hovland, 1961). Further support for this nonlinear effect comes from Monroe's (1971) price limit concept. According to Monroe, there is a price that customers consider unacceptably high, so their WTP will not increase beyond this threshold. In this respect, Nieto-García, Muñoz-Gallego, and González-Benito (2017) find empirical support for a quadratic relationship between IRP and tourists' WTP for accommodation. The present study replicates Nieto-García et al.'s (2017) hypothesis by predicting a curvilinear effect of IRP on WTP, such that the effect of IRP is positive up to a threshold, and then WTP decreases. Formally: 
H3. The relationship between internal reference prices and WTP follows an inverted Ushaped function.

In the previous sections, this study has proposed that travel frequency has a positive effect on IRP, which in turn affects customers' WTP. This means that IRP should have a mediating effect on the relationship between travel frequency and WTP. Therefore, the hypotheses development concludes by proposing the mediating effect of IRP on the relationship between travel frequency and WTP. Formally:

H4. IRP mediates the effect of travel frequency on WTP.

Figure 1 illustrates the proposed model.

[Insert Figure 1 around here]

\section{Methods}

\subsection{Measures}

Among the different methods to measure customers' WTP (Miller, Hofstetter, Krohmer, \& Zhang, 2011), the contingent valuation method (CVM) is particularly appropriate in the case of hypothetical situations (Kim, Wong, \& Cho, 2007). In this study, the measurement of WTP follows a specific CVM format (i.e., double-bound dichotomous choice, or DBDC). The DBDC format is statistically more efficient than the single-bound CVM (Hanemann, Loomis, \& Kanninen, 1991). In a DBDC format, participants consider a sequence of two bids and indicate whether their WTP equals or exceeds that bid. The sequence of bids is presented in Table 2. In the first bid, the starting price $(\mathrm{X})$ is set as the average market price for the corresponding accommodation type (INE, 2014). The value of the second bid depends on the answer (yes/no) to the first bid. If the answer to the first bid (i.e., average market price) is 
"Yes", the participant is then asked whether he or she will still buy the product at $\mathrm{X}+15 \%$. If the answer to the first bid is "No", the participant is asked whether he or she will buy the product at $\mathrm{X}-15 \%$. The $15 \%$ price difference between bids is similar to the manipulation in other studies that use the DBDC method (Li \& Meshkova, 2013). If the response to both bids is "Yes", the follow-up question is "What is the maximum you would pay for it?" If the response to both bids is "No", the follow-up question is "At what price, if any, would you be willing to book this accommodation?" The WTP is taken from the final price that the participant is willing to pay. They were not given any information about the actual price of the room.

All the respondents based their answers on a hypothetical accommodation. To ensure that both variables (IRP and WTP) referred to the same accommodation type, participants indicated their WTP for an accommodation of the same type as the one they used on their last holiday. Respondents could choose from three types of accommodation-i.e., hotel, apartment, or rural lodging, all of them in the business-to-consumer (B2C) domain. They all had the same information about the lodging facilities.

Purchase frequency denotes the number of purchases of the total product category in a specified period of time (Sharp \& Sharp, 1997). In this study, travel frequency is a continuous variable that reflects the times that the customer has booked an accommodation over the past 24 months, following the scales in previous studies (Karande \& Magnini, 2011; Meng \& Choi, 2016). We assume that the number of bookings equals the number of times that the participant has stayed in tourist accommodation. IRP uses the price the respondents paid for their last accommodation as a proxy, assuming that the last (most recent) price encountered is the main determinant of IRP (Kalyanaram \& Little, 1994; Nasiry \& Popescu, 2011). This is especially valid in the case of high-involvement purchase decisions that are time consuming, such as holiday accommodation (Torres et al., 2015). Furthermore, accommodation expenses 
represent a significant share of the customer's income. Under such circumstances, the customer will recall details of the last purchase more easily. Therefore, the last price paid appears to be a salient indicator of the unobservable IRP. This operationalization of IRP has been used in previous studies on consumer research (e.g., Chang, Siddarth, \& Weinberg, 1999; Krishnamurthi, Mazumdar, \& Raj, 1992; Mayhew \& Winer, 1992; Nieto-García et al., 2017).

Table 2 presents the measurement items.

[Insert Table 2 around here]

\subsection{Data collection and sample}

The data collection relies on an online panel of Spanish customers. The Sondea panel comprises more than 50,000 active panelists in Spain (Sondea, 2018). To ensure respondents are familiar with online accommodation booking, the web-based survey starts with two screening questions. The respondents indicate if they have stayed in accommodation for a holiday in the past 24 months. Those who answer "Yes" then state whether they searched the internet before booking. The survey underwent pilot testing with a convenience sample $(\mathrm{n}=$ 20) prior to the main study administration.

We used three sociodemographic characteristics (i.e., age, gender, and residence location) to build a sample frame that matches the study specifications. This guarantees that the sample is representative of the Spanish population. Participants were recruited randomly and were asked the two screening questions. Those who failed to pass the screening questions were replaced using random substitution. We also established some quotas for the different types of accommodation: $50 \%$ for hotel, $25 \%$ for apartment, and $25 \%$ for rural lodging. Once the 
hotel quota was reached (e.g., hotel), the recruitment focused on the remaining types of accommodation (i.e., apartment, rural lodging). A total of 564 respondents completed the survey. After removing incomplete questionnaires, the final sample comprised 551 responses.

The descriptive statistics for the study variables and the sociodemographic characteristics of the sample are in Table 3. Among the 551 respondents, 309 (56.1\%) are men, and 242 (43.9\%) are women. Most participants fall in the age groups of 35 to 44 years $(n=176$, $31.9 \%), 25$ to 34 years $(n=111,20.2 \%)$, or 45 to 54 years $(n=126,22.9 \%)$. With respect to their monthly income, $162(29.4 \%)$ earn less than $€ 1.800,176(31.9 \%)$ take in $€ 1,800$ $€ 3,000,135(24.5 \%)$ earn more than $€ 3,000$, and the rest $(n=78,14.2 \%)$ did not answer. Most of the respondents indicated that they are either university graduates $(n=264,47.9 \%)$ or had achieved a high school or technical certificate $(n=241,43.7 \%)$. Finally, $398(72.2 \%)$ are employed.

The respondents have booked accommodation 3.64 times on average in the past 24 months. The mean values of IRP and WTP are 35.73 and 36.50, respectively, and their correlation is 0.292 , indicating no perfect collinearity between these variables.

[Insert Table 3 around here]

\subsection{Data analysis}

The empirical analysis follows the methods proposed by Hayes and Preacher (2010). This approach is appropriate for testing indirect effects in mediation models in which the constituent paths are nonlinear but depend on the level of the independent variable (i.e., instantaneous indirect effects). A causal step approach (Baron \& Kenny, 1986) or Sobel test (Sobel, 1982) becomes problematic when linearity assumptions about the functional form of 
the relationship among variables is violated (Hayes, 2009). To resolve this issue, Hayes and Preacher (2010, p. 630) introduce the "instantaneous indirect effect of X on Y through M", as depicted in the mediation model in Equations 1 and 2:

$$
\begin{aligned}
& \widehat{M}=\mathrm{i}_{1}+\mathrm{aX} \\
& \widehat{Y}=\mathrm{i}_{2}+\mathrm{bM}+\mathrm{c}^{\prime} \mathrm{X}
\end{aligned}
$$

where the total effect of $\mathrm{X}$ on $\mathrm{Y}$ (Equation 3 ) is the sum of the direct and indirect effects, $\mathrm{c}=$ $a b+c^{\prime}:$

$$
\widehat{Y}=\mathrm{i}_{3}+\mathrm{cX}
$$

If $\mathrm{M}$ is a linear function of $\mathrm{X}$, and $\mathrm{Y}$ is a linear function of $\mathrm{M}, a$ quantifies the rate of change in $\mathrm{M}$ as $\mathrm{X}$ is changing, and $b$ quantifies the rate of change in $\mathrm{Y}$ as $\mathrm{M}$ is changing. That is, $\mathrm{Y}$ changes by $a b$ units through $\mathrm{M}$ as $\mathrm{X}$ changes by one unit. $\theta$ denotes the rate at which a change in $\mathrm{X}$ changes $\mathrm{Y}$ indirectly through changes in $\mathrm{M}$, and it is estimated as:

$$
\theta=\left(\frac{\partial M}{\partial X}\right)\left(\frac{\partial Y}{\partial M}\right)
$$

where $\theta$ represents the instantaneous indirect effect of $\mathrm{X}$ on $\mathrm{Y}$ through $\mathrm{M}$ at a specific value $\mathrm{X}=x$. As a function of $\mathrm{X}, \theta$ quantifies the change in $\mathrm{Y}$ through $\mathrm{M}$ as $\mathrm{X}$ is changing. If $\mathrm{M}$ is linear in $\mathrm{X}$, and $\mathrm{Y}$ is linear in $\mathrm{M}$, then $\theta$ is constant; but for any other functions for $\mathrm{M}$ or $\mathrm{Y}, \theta$ is a function of $X$.

Equations 4, 5, and 6 present the application of this approach to the current study. The quadratic terms in the regressions account for the proposed nonlinear effects. Centering the variables helps alleviate multicollinearity concerns between the main effects and quadratic terms. 
To avoid confounding effects of the different accommodation types, the analysis uses the variable 'Accommodation' as a control variable that takes a value of 0 when the accommodation is a hotel and 1 otherwise. Gender, age, education, income, and employment do not have significant effects on the dependent variables $(\mathrm{p}<0.01)$; therefore they are not included as control variables for the sake of parsimony.

$$
\begin{aligned}
& \mathrm{IRP}=\alpha_{2}+\beta_{1 \mathrm{~b}} \cdot \mathrm{TF}+\mathrm{AC}+\mathrm{e}_{2} \\
& \mathrm{WTP}=\alpha_{3}+\beta_{1 \mathrm{c}} \cdot \mathrm{IRP}+\beta_{2 \mathrm{c}} \cdot \mathrm{IRP}^{2}+\mathrm{AC}+\mathrm{e}_{3} \\
& \mathrm{WTP}=\alpha_{1}+\beta_{1 \mathrm{a}} \cdot \mathrm{TF}+\beta_{2 \mathrm{a}} \cdot \mathrm{TF}^{2}+\mathrm{AC}+\mathrm{e}_{1}
\end{aligned}
$$

where $\alpha$ and $\beta$ are estimated regression weights derived from ordinary least squares (OLS), WTP indicates willingness to pay, TF is travel frequency, IRP refers to internal reference price, $\mathrm{AC}$ is a control variable for accommodation type, and e is the error term.

The estimation of the model consists of two steps. First, OLS regression tests the direct effects; then the analysis tests the indirect effect with the correspondent linear and quadratic paths. In line with the OLS regression results, the paths IRP-WTP and travel frequencyWTP are set to be quadratic, and the path travel frequency-IRP is linear. The MEDCURVE macro for SPSS (Hayes \& Preacher, 2010) allows the estimation of the model.

We use the bias-corrected bootstrap test of mediation. This method affords the most accurate confidence limits and the greatest statistical power (MacKinnon, Lockwood, \& Williams, 2004). A random sample is taken from the original data with replacement and the indirect effect is computed. This process is repeated a large number of times, resulting in a bootstrap distribution. This test contains a correction for the bias created by the central tendency of the estimate (Efron \& Tibshirani, 1994; Fritz \& MacKinnon, 2007; Manly, 2006). The upper and lower confidence limits are: 


$$
\begin{aligned}
& \mathrm{z}_{\mathrm{u}}=2 \mathrm{z}_{0}+\mathrm{z}_{\mathrm{p}} \\
& \mathrm{z}_{\mathrm{l}}=2 \mathrm{z}_{0}-\mathrm{z}_{\mathrm{p}}
\end{aligned}
$$

where $\mathrm{z}_{\mathrm{u}}$ is the upper limit, $\mathrm{z}_{\mathrm{l}}$ is the lower limit, $\mathrm{z}_{0}$ is the bias or the proportion of bootstrapsample parameter estimates that are below the parameter estimate of the original sample, $p=$ $1-w / 2$ with $w$ equal to the Type I error rate, and $z_{p}=100 * p$.

\section{Results}

As Table 4 reveals, the relationship between travel frequency and WTP is significant and quadratic $(\beta=-0.669 ; \mathrm{p}<0.05)$ indicating that, in line with $\mathrm{H} 1$, customers are willing to pay more as travel frequency increases up to a point (i.e., travel frequency $=6$ ), after which their WTP starts to decrease.

The results also suggest a significant, positive relationship between travel frequency and IRP $(\beta=4.749 ; p<0.001)$, as H2 predicts. Customers' IRP increases as their travel frequency increases. The quadratic relationship between IRP and WTP proposed in H3 also receives support. The relationship is significant $(\beta=-0.001 ; p<0.001)$, such that as IRP increases, WTP increases to a point; beyond this threshold, WTP starts to decrease, suggesting a nonlinear effect, and so the relationship follows an inverted U-shape.

[Insert Table 4 around here]

Figures $2 \mathrm{a}, 2 \mathrm{~b}$, and 2c illustrate the effect of TF on IRP (Equation 9), the effect of IRP on WTP (Equation 10), and the effect of TF on WTP (Equation 11) respectively:

$$
\begin{aligned}
& \mathrm{IRP}=11.104+4.749 * \mathrm{TF} \\
& \mathrm{WTP}=41.026+0.172 * \mathrm{IRP}-0.001 *(\mathrm{IRP})^{2}
\end{aligned}
$$




$$
\mathrm{WTP}=42.265+2.556^{*} \mathrm{TF}-0.669 *(\mathrm{TF})^{2}
$$

[Insert Figures 2a, 2b, and 2c around here]

The results in Table 4 indicate that the effect of purchase frequency on WTP is not significant when IRP is included in the model (last column), suggesting the full mediation of IRP in the relationship between purchase frequency and WTP. To validate this preliminary result, it is necessary to assess the instantaneous indirect effect of IRP at different levels of purchase frequency.

This study uses bootstrapping to determine whether the instantaneous indirect effect is significantly different from zero. Bootstrapping serves to provide confidence intervals without assumptions about the shape of the sampling distribution. Results are stable across $1,000,5,000$, and 10,000 bootstrap samples estimations. Table 5 presents the confidence intervals for the instantaneous indirect effect $(\theta)$ with 1,000 bootstrap samples. The sample mean, as well as plus and minus one standard deviation from the sample mean, are the values of travel frequency at which the instantaneous indirect effect is estimated. The confidence interval does not contain zero, which means the parameter $\theta$ is statistically different from 0 . Therefore, the instantaneous indirect effect occurs at different levels of travel frequency. This suggests that increasing travel frequency leads to an increase in WTP through changes in customers' IRP. In turn, IRP mediates the effect of travel frequency on WTP at different levels of travel frequency, in support of $\mathrm{H} 4$.

[Insert Table 5 around here] 


\section{General discussion}

The effective alignment of prices with customers' valuations is key to maximize sellers' profits (Kim, Natter, \& Spann, 2009). Customers differ in the way they process price information, which places customer heterogeneity at the core of pricing (Moon et al., 2006). Customer-centric pricing entails a deep insight into customer buying behavior in order to align prices with each customer's WTP (Cross \& Dixit, 2005).

Past experiences with the service determine customers' prior knowledge, thereby creating customer heterogeneity (Moon et al., 2006). Previous studies in hospitality research emphasize the role of reference price in shaping customer reactions to prices (e.g., Choi et al., 2017; Choi \& Mattila, 2017; Viglia et al., 2016). However, previous research has paid scant attention to the influence of travel frequency on customer's internal norms and reactions to newly encountered prices (Karande \& Magnini, 2011). The findings from this study reveal the effect of travel frequency, as an indicator of familiarity with the service, on IRP and WTP for the accommodation.

Specifically, the results indicate a curvilinear relationship between travel frequency and WTP. Travel frequency exerts a positive influence on WTP, but after a certain level—in this study, approximately six times in the previous 24 months - greater frequency does not lead to higher WTP. This finding supports the notion that past consumption experience with the product category positively affects WTP, but beyond a threshold, the habituation effect occurs. Customers become more sensitive to price during the habituation phase, and higher frequency prompts them to search for the best deal, thereby decreasing their WTP. More importantly, IRP emerges as a mediator in the relationship between travel frequency and WTP — that is, travel frequency exerts a positive impact on IRP, such that frequent travelers exhibit high IRP, and IRP has a positive impact on WTP. Increasing travel frequency leads to 
higher price tolerance and therefore a shift in IRP. This effect does not always translate into higher WTP, but it depends on the level of IRP. When IRP reaches a certain threshold, newly encountered prices above this threshold create a contrast effect that results in decreasing WTP for the accommodation. This result is in line with Sherif and Hovland's (1961) assimilation contrast theory, suggesting that when the newly encountered price is too high, a contrast effect occurs, dissuading the customer from accepting that price.

The current research offers a number of theoretical contributions. Firstly, while travel frequency has been investigated previously (e.g., Losada, Alén, Domínguez, \& Nicolau, 2016), this study presents the first attempt to propose travel frequency as a determinant of travelers' WTP for an accommodation. Secondly, by introducing the concept of consumer habituation (Wathieu, 2004), this study advances our theoretical knowledge on how past experiences shape travelers' WTP. The findings of this study show that leisure travelers experience habituation when their travel frequency reaches a certain level. Once travelers reach the habituation phase, increasing travel frequency has a negative impact on travelers' WTP for the accommodation. These findings suggest that further research on WTP should adopt a customer-centric focus, taking into account that customers' reactions to prices are determined by their IRP. Building on Choi et al.'s (2017) exploration of the effects of internal and external reference prices on price evaluation, this study provides a deeper understanding of the role of IRP in purchase decisions. IRP is affected by travel frequency, and it emerges as the key mechanism through which travel frequency influences WTP. Finally, the novel methodological approach provides additional insights into the need to evaluate the instantaneous indirect effect when testing relationships in which the paths are nonlinear. 


\section{Managerial implications}

In recent years, hotel revenue management has evolved from an inventory management technique into a more strategic, customer-centric marketing tool (Wroten, 2018). Price optimization requires an understanding of customer buying habits to predict what each customer is willing to pay. Therefore, RM professionals are increasingly using marketing analytics to develop individual customer pricing (Cross, Higbie, \& Cross, 2009; Kimes, 2017).

Our results deliver a clear message to RM professionals in the hospitality industry. In addition to information from the booking request, such as length of stay (Riasi, Schwartz, Liu, \& Li, 2017), pricing models should track individual customers' purchase patterns. Specifically, our results show that customers who have traveled six times in the past two-year period are willing to accept higher room rates. In contrast, low and high frequency travelers seem to be more sensitive to price. These findings highlight that price premiums could be achieved by using a pricing strategy that pays more attention to customers' transactions, specifically travel frequency and last prices paid. By effectively using information from loyalty programs and CRM systems, RM professionals will be able to set room rates in a more personalized way (Kimes, 2017). This customer-centric approach would result in better alignment of prices with travelers' WTP, which is crucial for revenue maximization.

Furthermore, the current study shows evidence of customer habituation in the hospitality industry. In light of this, a question arises as to how the industry should tackle the habituation effect that damages customers' WTP. A possible solution could be the implementation of service personalization (Piccoli, Lui, \& Grün, 2017). Personalized offers will ensure the salience of external cues — i.e., personalized attributes — in price evaluations. Drawing customer attention to external cues will help counteract the pervasive effect of internal norms 
on WTP. Such a customer-centric strategy would enhance each customer's profitability and lifetime value (Noone et al., 2017).

\section{Limitations and further research}

The present study is not without limitations. The analytical procedure used to estimate the indirect effect with nonlinear paths assumes accurate model specification based on theoretical predictions or prior findings (Hayes \& Preacher, 2010). Although this study relies on Wathieu's (2004) theoretical contribution that supports a nonlinear relationship between purchase frequency and WTP, further theoretical evidence would allow a more solid model specification.

This study intends to serve as the initial step toward untangling the effect of customer prior experience on WTP, but the understanding of customer habituation in the hospitality sector remains less than comprehensive. Further research should investigate the influence of recency. The recency-frequency-monetary value model (RFM model) suggests that recency plays a role in shaping customer valuations (Fader, Hardie, \& Lee, 2005; Malthouse \& Blattberg, 2005). The present study states that frequency and monetary value, in the form of IRP, affect WTP regardless of the time elapsed since the last transaction. However, prices encountered more recently have stronger effects than those encountered longer ago (Mazumdar et al., 2005). Therefore, the inclusion of a recency parameter could result in an even more accurate and flexible model.

The cross-sectional design is also a notable limitation. The static WTP model proposed herein relies on survey data to test the hypotheses. To confirm the generalizability of the results, researchers might adopt a panel data structure to leverage all available data for model calibration. This might overcome some limitations of the present study by accounting for multiple periods of purchasing behavior, such as one to define the independent variable 
(travel frequency) and another to arrive at the values of the dependent variables (IRP and WTP).

While this study provides interesting insights in the context of leisure travelers, future studies may explore the habituation effect for business travelers, given their unique travel patterns. Finally, this study focuses on traditional tourist accommodation. Future research could also extend the analysis to other hospitality services in which the role of customers' prior experience might be even more salient (e.g., the sharing economy). Future studies should take into consideration the unique nature of peer-to-peer transactions, where the host often plays a key role in the experience (Ert, Fleischer, \& Magen, 2016). In this domain, travelers bring a special set of attributes - i.e., interaction with the host - into their price evaluations. 


\section{References}

Abrate, G., Fraquelli, G., \& Viglia, G. (2012). Dynamic pricing strategies: Evidence from European hotels. International Journal of Hospitality Management, 31(1), 160-168.

Adaval, R., \& Wyer Jr, R. S. (2011). Conscious and nonconscious comparisons with price anchors: Effects on willingness to pay for related and unrelated products. Journal of Marketing Research, 48(2), 355-365.

Alba, J. W., \& Hutchinson, J. W. (1987). Dimensions of consumer expertise. Journal of Consumer Research, 13(4), 411-454.

Baron, R. M., \& Kenny, D. A. (1986). The moderator-mediator variable distinction in social psychological research: Conceptual, strategic, and statistical considerations. Journal of Personality and Social Psychology, 51(6), 1173-1182.

Baucells, M., \& Sarin, R. K. (2010). Predicting utility under satiation and habit formation. Management Science, 56(2), 286-301.

Bettman, J. R. (1979). Memory factors in consumer choice: A review. The Journal of Marketing, 43(2), 37-53.

Bettman, J. R., \& Park, C. W. (1980). Effects of prior knowledge and experience and phase of the choice process on consumer decision processes: A protocol analysis. Journal of Consumer Research, 7(3), 234-248.

Biswas, A. (1992). The moderating role of brand familiarity in reference price perceptions. Journal of Business Research, 25(3), 251-262.

Biswas, A., \& Blair, E. A. (1991). Contextual effects of reference prices in retail advertisements. Journal of Marketing, 55(3), 1-12.

Briesch, R. A., Krishnamurthi, L., Mazumdar, T., \& Raj, S. P. (1997). A comparative analysis of reference price models. Journal of Consumer Research, 24(2), 202-214. 
Cameron, T. A., \& James, M. D. (1987). Estimating willingness to pay from survey data: An alternative pre-test-market evaluation procedure. Journal of Marketing Research, 69(2), $389-395$.

Chang, K., Siddarth, S., \& Weinberg, C. B. (1999). The impact of heterogeneity in purchase timing and price responsiveness on estimates of sticker shock effects. Marketing Science, 18(2), 178-192.

Chatterjee, P., \& Kumar, A. (2017). Consumer willingness to pay across retail channels. Journal of Retailing and Consumer Services, 34, 264-270.

Cheng, L. L., \& Monroe, K. B. (2013). An appraisal of behavioral price research (part 1): price as a physical stimulus. AMS Review, 3(3), 103-129.

Choi, C., Joe, S. J., \& Mattila, A. S. (2017). Reference price and its asymmetric effects on price evaluations: The moderating role of gender. Cornell Hospitality Quarterly. doi:1938965517719266.

Choi, S., \& Mattila, A. S. (2006). The role of disclosure in variable hotel pricing: A crosscultural comparison of customers' fairness perceptions. Cornell Hotel and Restaurant Administration Quarterly, 47(1), 27-35.

Choi, C., \& Mattila, A. S. (2017). The effects of internal and external reference prices on travelers' price evaluations. Journal of Travel Research. doi:0047287517735910.

Clarke, K., \& Belk, R. W. (1979). The effects of product involvement and task definition on anticipated consumer effort. Advances in Consumer Research, 6, 313-318.

Cordell, V. V. (1997). Consumer knowledge measures as predictors in product evaluation. Psychology \& Marketing, 14(3), 241-260.

Coupey, E., Irwin, J. R., \& Payne, J. W. (1998). Product category familiarity and preference construction. Journal of Consumer Research, 24(4), 459-468. 
Cross, R. G., \& Dixit, A. (2005). Customer-centric pricing: The surprising secret for profitability. Business Horizons, 48(6), 483-491.

Cross, R. G., Higbie, J. A., \& Cross, D. Q. (2009). Revenue management's renaissance: A rebirth of the art and science of profitable revenue generation. Cornell Hospitality Quarterly, 50(1), 56-81.

Cummings, W. T., \& Ostrom, L. L. (1982). Measuring price thresholds using social judgment theory. Journal of the Academy of Marketing Science, 10(4), 395-409.

de la Peña, M. R., Núñez-Serrano, J. A., Turrión, J., \& Velázquez, F. J. (2016). Are innovations relevant for consumers in the hospitality industry? A hedonic approach for Cuban hotels. Tourism Management, 55, 184-196.

Denizci Guillet, B., \& Mohammed, I. (2015). Revenue management research in hospitality and tourism: A critical review of current literature and suggestions for future research. International Journal of Contemporary Hospitality Management, 27(4), 526-560.

Divine, R. L. (1995). The influence of price on the relationship between involvement and consideration set size. Marketing Letters, 6(4), 309-319.

Dogerlioglu-Demir, K., \& Koçaş, C. (2015). Seemingly incidental anchoring: the effect of incidental environmental anchors on consumers' willingness to pay. Marketing Letters, 26(4), 607-618.

Duetto, 2019. The Ultimate Guide to Hotel Revenue Strategy, Duetto. Retrieved from http://www.duettoresearch.com/resources/ultimateguide.pdf

Dutta, K., Parsa, H., Parsa, R. A., \& Bujisic, M. (2014). Change in consumer patronage and willingness to pay at different levels of service attributes in restaurants: A study in India. Journal of Quality Assurance in Hospitality \& Tourism, 15(2), 149-174. 
Efron, B., \& Tibshirani, R. J. (1994). An introduction to the bootstrap. New York: CRC Press.

Ert, E., Fleischer, A., \& Magen, N. (2016). Trust and reputation in the sharing economy: The role of personal photos in Airbnb. Tourism Management, 55, 62-73.

Estelami, H., \& De Maeyer, P. (2004). Product category determinants of price knowledge for durable consumer goods. Journal of Retailing, 80(2), 129-137.

Fader, P. S., Hardie, B. G., \& Lee, K. L. (2005). RFM and CLV: Using iso-value curves for customer base analysis. Journal of Marketing Research, 42(4), 415-430.

Fodness, D., \& Murray, B. (1998). A typology of tourist information search strategies. Journal of Travel Research, 37(2), 108-119.

Fritz, M. S., \& MacKinnon, D. P. (2007). Required sample size to detect the mediated effect. Psychological Science, 18(3), 233-239.

Gabor, A., \& Granger, C. W. (1961). On the price consciousness of consumers. Journal of the Royal Statistical Society: Series C (Applied Statistics), 10(3), 170-188.

Groves, P. M., \& Thompson, R. F. (1970). Habituation: A dual-process theory. Psychological Review, 77(5), 419-450.

Gruber, V., Schlegelmilch, B. B., \& Houston, M. J. (2014). Inferential evaluations of sustainability attributes: Exploring how consumers imply product information. Psychology \& Marketing, 31(6), 440-450.

Gursoy, D., \& McCleary, K. W. (2004a). An integrative model of tourists' information search behavior. Annals of Tourism Research, 31(2), 353-373.

Gursoy, D., \& McCleary, K. W. (2004b). Travelers' prior knowledge and its impact on their information search behavior. Journal of Hospitality \& Tourism Research, 28(1), 66-94. 
Hanemann, M., Loomis, J., \& Kanninen, B. (1991). Statistical efficiency of double-bounded dichotomous choice contingent valuation. American Journal of Agricultural Economics, 73(4), 1255-1263.

Hayes, A. F. (2009). Beyond Baron and Kenny: Statistical mediation analysis in the new millennium. Communication Monographs, 76(4), 408-420.

Hayes, A. F., \& Preacher, K. J. (2010). Quantifying and testing indirect effects in simple mediation models when the constituent paths are nonlinear. Multivariate Behavioral Research, 45(4), 627-660.

Helson, H. (1964). Adaptation-level theory: An experimental and systematic approach to behavior. New York, NY: Harper and Row.

Heo, C. Y., \& Hyun, S. S. (2015). Do luxury room amenities affect guests' willingness to pay? International Journal of Hospitality Management, 46, 161-168.

Herrmann, A., Huber, F., Sivakumar, K., \& Wricke, M. (2004). An empirical analysis of the determinants of price tolerance. Psychology \& Marketing, 21(7), 533-551.

Hofstetter, R., Miller, K. M., Krohmer, H., \& Zhang, Z. J. (2013). How do consumer characteristics affect the bias in measuring willingness to pay for innovative products? Journal of Product Innovation Management, 30(5), 1042-1053.

Homburg, C., Koschate, N., \& Hoyer, W. D. (2005). Do satisfied customers really pay more? A study of the relationship between customer satisfaction and willingness to pay. Journal of Marketing, 69(2), 84-96.

INE, 2014. Coyuntura turística hotelera 2014, Instituto Nacional de Estadística. Retrieved from http://www.ine.es/daco/daco42/prechote/cth1214.pdf

Johnson, E. J., \& Russo, J. E. (1984). Product familiarity and learning new information. Journal of Consumer Research, 11(1), 542-550. 
Kalyanaram, G., \& Little, J. D. (1994). An empirical analysis of latitude of price acceptance in consumer package goods. Journal of Consumer Research, 21(3), 408-418.

Kalyanaram, G., \& Winer, R. S. (1995). Empirical generalizations from reference price research. Marketing Science, 14(3), 161-169.

Kang, K. H., Stein, L., Heo, C. Y., \& Lee, S. (2012). Consumers' willingness to pay for green initiatives of the hotel industry. International Journal of Hospitality Management, 31(2), $564-572$.

Karande, K., \& Magnini, V. P. (2011). The relative use of contextual and temporal reference price components in hotel and airline purchases. Journal of Hospitality \& Tourism Research, 35(1), 119-141.

Kim, Y., \& Han, H. (2010). Intention to pay conventional-hotel prices at a green hotel: A modification of the theory of planned behavior. Journal of Sustainable Tourism, 18(8), $997-1014$.

Kim, J., Natter, M., \& Spann, M. (2009). Pay what you want: A new participative pricing mechanism. Journal of Marketing, 73(1), 44-58.

Kim, B., \& Rossi, P. E. (1994). Purchase frequency, sample selection, and price sensitivity: The heavy-user bias. Marketing Letters, 5(1), 57-67.

Kim, S. S., Wong, K. K., \& Cho, M. (2007). Assessing the economic value of a world heritage site and willingness-to-pay determinants: A case of Changdeok palace. Tourism Management, 28(1), 317-322.

Kimes, S. E. (2017). The future of hotel revenue management. Cornell Hospitality Report, 17(1), 3-10.

Koschate-Fischer, N., Diamantopoulos, A., \& Oldenkotte, K. (2012). Are consumers really willing to pay more for a favorable country image? A study of country-of-origin effects on willingness to pay. Journal of International Marketing, 20(1), 19-41. 
Koschate-Fischer, N., Stefan, I. V., \& Hoyer, W. D. (2012). Willingness to pay for causerelated marketing: The impact of donation amount and moderating effects. Journal of Marketing Research, 49(6), 910-927.

Krishnamurthi, L., Mazumdar, T., \& Raj, S. P. (1992). Asymmetric response to price in consumer brand choice and purchase quantity decisions. Journal of Consumer Research, 19(3), 387-400.

Kuminoff, N. V., Zhang, C., \& Rudi, J. (2010). Are travelers willing to pay a premium to stay at a "green" hotel? Evidence from an internal meta-analysis of hedonic price premia. Agricultural and Resource Economics Review, 39(3), 468-484.

Li, T., \& Meshkova, Z. (2013). Examining the impact of rich media on consumer willingness to pay in online stores. Electronic Commerce Research and Applications, 12(6), 449461.

Lichtenstein, D. R., Bloch, P. H., \& Black, W. C. (1988). Correlates of price acceptability. Journal of Consumer Research, 15(2), 243-252.

Losada, N., Alén, E., Domínguez, T., \& Nicolau, J. L. (2016). Travel frequency of seniors tourists. Tourism Management, 53, 88-95.

MacKinnon, D. P., Lockwood, C. M., \& Williams, J. (2004). Confidence limits for the indirect effect: Distribution of the product and resampling methods. Multivariate Behavioral Research, 39(1), 99-128.

Malthouse, E. C., \& Blattberg, R. C. (2005). Can we predict customer lifetime value? Journal of Interactive Marketing, 19(1), 2-16.

Manly, B. F. (2006). Randomization, bootstrap and Monte Carlo methods in biology. New York: Chapman and Hall/CRC. 
Masiero, L., Heo, C. Y., \& Pan, B. (2015). Determining guests' willingness to pay for hotel room attributes with a discrete choice model. International Journal of Hospitality Management, 49, 117-124.

Masiero, L., Nicolau, J. L., \& Law, R. (2015). A demand-driven analysis of tourist accommodation price: A quantile regression of room bookings. International Journal of Hospitality Management, 50, 1-8.

Mayhew, G. E., \& Winer, R. S. (1992). An empirical analysis of internal and external reference prices using scanner data. Journal of Consumer Research, 19(1), 62-70.

Mazumdar, T., \& Monroe, K. B. (1990). The effects of buyers' intentions to learn price information. Journal of Retailing, 66(1), 15-32.

Mazumdar, T., Raj, S., \& Sinha, I. (2005). Reference price research: Review and propositions. Journal of Marketing, 69(4), 84-102.

Meng, B., \& Choi, K. (2016). The role of authenticity in forming slow tourists' intentions: Developing an extended model of goal-directed behavior. Tourism Management, 57, $397-410$.

Miller, K. M., Hofstetter, R., Krohmer, H., \& Zhang, Z. J. (2011). How should consumers' willingness to pay be measured? An empirical comparison of state-of-the-art approaches. Journal of Marketing Research, 48(1), 172-184.

Monroe, K. B. (1971). Measuring price thresholds by psychophysics and latitudes of acceptance. Journal of Marketing Research, 8(4), 460-464.

Monroe, K. B. (1973). Buyers' subjective perceptions of price. Journal of Marketing Research, 10(1), 70-80.

Monroe, K.B. (2002). Pricing-Making profitable decisions (3rd ed.). New York: McGrawHill. 
Monroe, K. B., \& Lee, A. Y. (1999). Remembering versus knowing: Issues in buyers' processing of price information. Journal of the Academy of Marketing Science, 27(2), $207-225$.

Monty, B., \& Skidmore, M. (2003). Hedonic pricing and willingness to pay for bed and breakfast amenities in southeast Wisconsin. Journal of Travel Research, 42(2), 195-199.

Moon, S., Russell, G. J., \& Duvvuri, S. D. (2006). Profiling the reference price consumer. Journal of Retailing, 82(1), 1-11.

Nagle, T.T., \& Holden, R.K. (2002). The strategy and tactics of pricing: A guide to profitable decision making. Upper Saddle River, New Jersey: Prentice Hall.

Nasiry, J., \& Popescu, I. (2011). Dynamic pricing with loss-averse consumers and peak-end anchoring. Operations Research, 59(6), 1361-1368.

Nieto-García, M., Muñoz-Gallego, P. A., \& González-Benito, Ó. (2017). Tourists' willingness to pay for an accommodation: The effect of eWOM and internal reference price. International Journal of Hospitality Management, 62, 67-77.

Noone, B. M., Enz, C. A., \& Glassmire, J. (2017). Total hotel revenue management: A strategic profit perspective. Cornell Hospitality Report, 17(8), 3-15.

Nunes, J. C., \& Boatwright, P. (2004). Incidental prices and their effect on willingness to pay. Journal of Marketing Research, 41(4), 457-466.

Pan, B., Zhang, L., \& Law, R. (2013). The complex matter of online hotel choice. Cornell Hospitality Quarterly, 54(1), 74-83.

Park, C. W., Mothersbaugh, D. L., \& Feick, L. (1994). Consumer knowledge assessment. Journal of Consumer Research, 21(1), 71-82. 
Piccoli, G., Lui, T. W., \& Grün, B. (2017). The impact of IT-enabled customer service systems on service personalization, customer service perceptions, and hotel performance. Tourism Management, 59, 349-362.

Rajendran, K. N., \& Tellis, G. J. (1994). Contextual and temporal components of reference price. Journal of Marketing, 58(1), 22-34.

Rao, A. R., \& Sieben, W. A. (1992). The effect of prior knowledge on price acceptability and the type of information examined. Journal of Consumer Research, 19(2), 256-270.

Ratchford, B. T. (2001). The economics of consumer knowledge. Journal of Consumer Research, 27(4), 397-411.

Riasi, A., Schwartz, Z., Liu, X., \& Li, S. (2017). Revenue management and length-of-staybased room pricing. Cornell Hospitality Quarterly, 58(4), 393-399.

Sharp, B., \& Sharp, A. (1997). Loyalty programs and their impact on repeat-purchase loyalty patterns. International Journal of Research in Marketing, 14(5), 473-486.

Sherif, M., \& Hovland, C. I. (1961). Social judgment: Assimilation and contrast effects in communication and attitude change. Westport, CT: Greenwood Press.

Sobel, M. E. (1982). Asymptotic confidence intervals for indirect effects in structural equation models. Sociological Methodology, 13, 290-312.

Sondea. (2018). Metodología. Retrieved from https://www.sondea.com/

Sukhu, A., Bilgihan, A., \& Seo, S. (2017). Willingness to pay in negative restaurant service encounters. International Journal of Hospitality Management, 65, 11-19.

Tang, C. M. F., \& Lam, D. (2017). The role of extraversion and agreeableness traits on gen Y's attitudes and willingness to pay for green hotels. International Journal of Contemporary Hospitality Management, 29(1), 607-623. 
Teare, R. (1992). An exploration of the consumer decision process for hospitality services. In R. Teare, L. Moutinho, \& N. J. Morgan (Eds.). Managing and marketing services in the 1990s (pp. 233-248). London, UK: Cassell Educational

Torres, E. N., Singh, D., \& Robertson-Ring, A. (2015). Consumer reviews and the creation of booking transaction value: Lessons from the hotel industry. International Journal of Hospitality Management, 50, 77-83.

Tu, Y., Neuhofer, B., \& Viglia, G. (2018). When co-creation pays: Stimulating engagement to increase revenues. International Journal of Contemporary Hospitality Management, 30(4), 2093-2111.

Viglia, G., \& Abrate, G. (2014). How social comparison influences reference price formation in a service context. Journal of Economic Psychology, 45, 168-180.

Viglia, G., Mauri, A., \& Carricano, M. (2016). The exploration of hotel reference prices under dynamic pricing scenarios and different forms of competition. International Journal of Hospitality Management, 52, 46-55.

Wathieu, L. (2004). Consumer habituation. Management Science, 50(5), 587-596.

Winer, R. S. (1986). A reference price model of brand choice for frequently purchased products. Journal of Consumer Research, 13(2), 250-256.

Wong, K. K., \& Kim, S. (2012). Exploring the differences in hotel guests' willingness-to-pay for hotel rooms with different views. International Journal of Hospitality \& Tourism Administration, 13(1), 67-93.

Wroten, B. (2018). Hotel revenue management is becoming revenue strategy. Retrieved from http://www.hotelnewsnow.com/Articles/290638/How-revenue-management-isbecoming-revenue-strategy 
Xu, X., \& Gursoy, D. (2015). Influence of sustainable hospitality supply chain management on customers' attitudes and behaviors. International Journal of Hospitality Management, 49, 105-116. 
Table 1. Review of academic papers on WTP in hospitality research

\begin{tabular}{|c|c|}
\hline Academic papers & WTP determinants \\
\hline $\begin{array}{l}\text { de la Peña, Núñez-Serrano, } \\
\text { Turrión, and Velázquez } \\
\text { (2016) }\end{array}$ & $\begin{array}{l}\text { Star rating, hotel size, hotel chain, diversification } \\
\text { customization, and specialization }\end{array}$ \\
\hline $\begin{array}{l}\text { Dutta, Parsa, Parsa, and } \\
\text { Bujisic (2014) }\end{array}$ & Service quality, food quality, ambience \\
\hline Heo and Hyun (2015) & Luxury amenities \\
\hline $\begin{array}{l}\text { Kang, Stein, Heo, and Lee } \\
(2012)\end{array}$ & Environmental concerns and hotel types \\
\hline Kim and Han (2010) & $\begin{array}{l}\text { Customers' environmental concerns, attitudes, and } \\
\text { beliefs. }\end{array}$ \\
\hline $\begin{array}{l}\text { Kuminoff, Zhang, and Rudi } \\
\text { (2010) }\end{array}$ & Green certification and hotel amenities \\
\hline $\begin{array}{l}\text { Masiero, Heo, and Pan } \\
(2015)\end{array}$ & $\begin{array}{l}\text { Hotel attributes (guest smartphone, free cancellation } \\
\text { view, floor, access to club, free mini bar, and price) }\end{array}$ \\
\hline $\begin{array}{l}\text { Masiero, Nicolau, and Law } \\
\text { (2015) }\end{array}$ & $\begin{array}{l}\text { Length of stay, advance booking, star rating, type of } \\
\text { accommodation, channel, seasonality, transaction party }\end{array}$ \\
\hline $\begin{array}{l}\text { Monty and Skidmore } \\
(2003)\end{array}$ & $\begin{array}{l}\text { Hotel attributes (location, room size, private bath, ho } \\
\text { tub, kitchen appliances, gift certificate, fireplace) }\end{array}$ \\
\hline Nieto-García et al. (2017) & $\begin{array}{l}\text { eWOM valence, eWOM volume, and internal reference } \\
\text { price }\end{array}$ \\
\hline $\begin{array}{l}\text { Sukhu, Bilgihan, and Seo } \\
\text { (2017) }\end{array}$ & $\begin{array}{l}\text { Service quality, food quality, ambience, and perceived } \\
\text { value }\end{array}$ \\
\hline Tang and Lam (2017) & $\begin{array}{l}\text { Extraversion, agreeableness, and attitudes towards green } \\
\text { hotels }\end{array}$ \\
\hline $\begin{array}{l}\text { Tu, Neuhofer, and Viglia } \\
(2018)\end{array}$ & Co-creation, customer engagement and frequency of stay \\
\hline Wong and Kim (2012) & $\begin{array}{l}\text { Room views, sociodemographic, psychological, anc } \\
\text { travel-related variables }\end{array}$ \\
\hline $\mathrm{Xu}$ and Gursoy (2015) & $\begin{array}{l}\text { Dimensions of sustainable hospitality supply chain } \\
\text { management }\end{array}$ \\
\hline
\end{tabular}

Main results

Customers are willing to pay more for hotels with greater innovative activity. Quality, diversification, customization, and the hotel chain increase the WTP.

The combination of high food quality and high ambience results in higher WTP compared to the combination of high food quality and high service quality.

When the room includes luxury amenities, customers' WTP increases. Customers perceive Wi-Fi as the most useful hotel amenity.

Hotel guests with a higher degree of environmental concerns have a higher WTP for hotels' green initiatives. Luxury and mid-priced hotel guests have higher WTP than economy hotel guests.

Customers' environmental concerns, attitudes, and beliefs contribute to forming the WTP for a green hotel.

Travelers are willing to pay a significant premium for a standard room in a green hotel.

Leisure travelers versus business travelers, and first-time visitors versus repeat visitors, manifest different WTP values for various hotel attributes.

The findings confirm the statistic relevance of all the variables used as explanatory factors of the accommodation expenditure.

Customers exhibit high WTP for specific characteristics such as a hot tub, a private bath, and a larger room. In contrast, fireplaces, themes, scenic views, and room service have no effect on WTP.

eWOM valence positively affects customers' WTP. Volume and internal reference price moderate this relationship. The effect of IRP follows an inverse U shape.

Food quality, ambience, and perceived value are significant predictors of customer WTP in a negative restaurant service encounter. Service quality does not influence customer WTP in negative restaurant service encounters.

Attitude toward green hotels mediates the relationship between personality traits (extraversion and agreeableness) and willingness to pay for green hotels. Attitudes that are more positive result in higher WTP.

Customer engagement mediates the impact of co-creation on WTP. Frequency of stay positively influences WTP.

Customers attribute the highest WTP value to a harbor view. The second highest WTP corresponds to a garden view. Customers show the lowest WTP for a room with an urban view.

Both environmental and economic dimensions' actions of sustainable hospitality supply chain management have positive effects on customer WTP for sustainable hospitality goods and services. The social dimension actions have a negative influence on customer WTP. 
Table 2. Measurement items

\begin{tabular}{ll}
\hline Variable & Measure \\
\hline Travel frequency & "How many times have you booked an accommodation over the past 24 months?" \\
\hline Accommodation & "In what type of accommodation did you stay on your last holiday?" \\
\hline
\end{tabular}

Q1. Considering your next holiday, if the accommodation you have just observed was in a location you were traveling to, would you book this accommodation at $€ \mathrm{X}$ per room (if hotel)/per person (otherwise), per night? (Accommodation only, VAT is included.)

Yes No

If participant answers 'Yes' to Q1, then Q2 follows:

Q2. Would you still book this accommodation at $€ X$ ?

Yes No

Willingness to pay

If participant answers 'Yes' to Q2, then Q3 follows:

Q3. What is the maximum price you would pay for it?

If participant answers 'No' to Q1, then Q4 follows:

Q4. Would you book this accommodation at $€ X$ then?

Yes No

If participant answers 'No' to Q4, then Q5 follows:

Q5. At what price, if any, would you be willing to book this accommodation?

"How much did you spend on accommodation on your last holiday?" 
Table 3. Descriptive statistics and socio-demographic characteristics of respondents

\begin{tabular}{|c|c|c|c|c|c|c|c|}
\hline Variable & Mean & Std. dev. & $25^{\text {th }} \mathrm{pct}$ & Median & $75^{\text {th }} \mathrm{pct}$ & Min & Max \\
\hline $\begin{array}{l}\text { Travel frequency } \\
\text { (times over the past } 24 \text { months) }\end{array}$ & 3.64 & 2.83 & 2 & 3 & 5 & 1 & 20 \\
\hline Internal reference price $(€)$ & 35.73 & 30.68 & 18.75 & 28.57 & 42.86 & 0.33 & 263.17 \\
\hline \multirow[t]{2}{*}{ Willingness to pay $(€)$} & 36.50 & 21.02 & 23 & 30 & 45 & 0 & 100 \\
\hline & $\mathrm{n}$ & $\%$ & & & & & \\
\hline \multicolumn{8}{|l|}{ Accommodation } \\
\hline Hotel & 271 & 49.2 & & & & & \\
\hline Other & 280 & 50.8 & & & & & \\
\hline \multicolumn{8}{|l|}{ Gender } \\
\hline Male & 309 & 56.1 & & & & & \\
\hline Female & 242 & 43.9 & & & & & \\
\hline \multicolumn{8}{|l|}{ Age } \\
\hline $18-24$ & 48 & 8.7 & & & & & \\
\hline $25-34$ & 111 & 20.2 & & & & & \\
\hline $35-44$ & 176 & 31.9 & & & & & \\
\hline $45-54$ & 126 & 22.87 & & & & & \\
\hline $55-65$ & 90 & 16.3 & & & & & \\
\hline \multicolumn{8}{|l|}{ Education } \\
\hline Secondary education & 46 & 8.4 & & & & & \\
\hline High school & 241 & 43.7 & & & & & \\
\hline University or above & 264 & 47.9 & & & & & \\
\hline \multicolumn{8}{|l|}{ Monthly household income } \\
\hline$<€ 1,800$ & 162 & 29.4 & & & & & \\
\hline$€ 1,800-€ 3,000$ & 176 & 31.9 & & & & & \\
\hline$>€ 3,000$ & 135 & 24.5 & & & & & \\
\hline Rather not answer & 78 & 14.2 & & & & & \\
\hline \multicolumn{8}{|l|}{ Occupation } \\
\hline Employed & 398 & 72.2 & & & & & \\
\hline Unemployed & 153 & 27.8 & & & & & \\
\hline Total & 551 & 100.00 & & & & & \\
\hline
\end{tabular}


Table 4. OLS regression analysis

\begin{tabular}{|c|c|c|c|c|c|c|c|c|}
\hline & \multicolumn{2}{|c|}{ D.V.: WTP (H1) } & \multicolumn{2}{|c|}{ D.V.: IRP (H2) } & \multicolumn{2}{|c|}{ D.V.: WTP (H3) } & \multicolumn{2}{|c|}{ Mediation model (H4) } \\
\hline & $\beta$ & Std. coef. & $\beta$ & Std. coef. & $\beta$ & Std. coef. & $\beta$ & Std. coef. \\
\hline Intercept & 42.265 & & 11.104 & & 41.026 & & 41.436 & \\
\hline $\mathrm{TF}$ & 2.556 & $0.124 *$ & 4.749 & $0.157 * * *$ & _- & _ & 2.075 & 0.101 \\
\hline$(\mathrm{TF})^{2}$ & -0.669 & $-0.116^{*}$ & - & - & - & _- & -0.607 & -0.106 \\
\hline IRP & - & - & _ & - & 0.172 & $0.253 * * *$ & 0.167 & $0.245^{* * *}$ \\
\hline$(\mathrm{IRP})^{2}$ & - & - & - & - & -0.001 & $-0.152 * *$ & -0.001 & $-0.150^{* *}$ \\
\hline $\mathrm{AC}$ & -20.124 & $-0.479 * * *$ & -21.888 & $-0.357 * * *$ & -17.517 & $-0.417 * * *$ & -17.234 & $-0.410 * * *$ \\
\hline$R$-squared & & 0.308 & & 0.166 & & 0.324 & & 0.328 \\
\hline Adj. R-squared & & 0.303 & & 0.163 & & 0.319 & & 0.321 \\
\hline
\end{tabular}


Table 5. Instantaneous indirect effect (theta) of travel frequency on WTP through IRP

\begin{tabular}{ccccc}
\hline Travel frequency value & Theta $\theta$ & Std. error & Lower CI & Upper CI \\
\hline 0.811 & 0.818 & 0.412 & 0.265 & 2.021 \\
3.640 & 0.783 & 0.379 & 0.259 & 1.886 \\
6.469 & 0.748 & 0.347 & 0.256 & 1.743 \\
\hline
\end{tabular}


Figure 1. Conceptual model

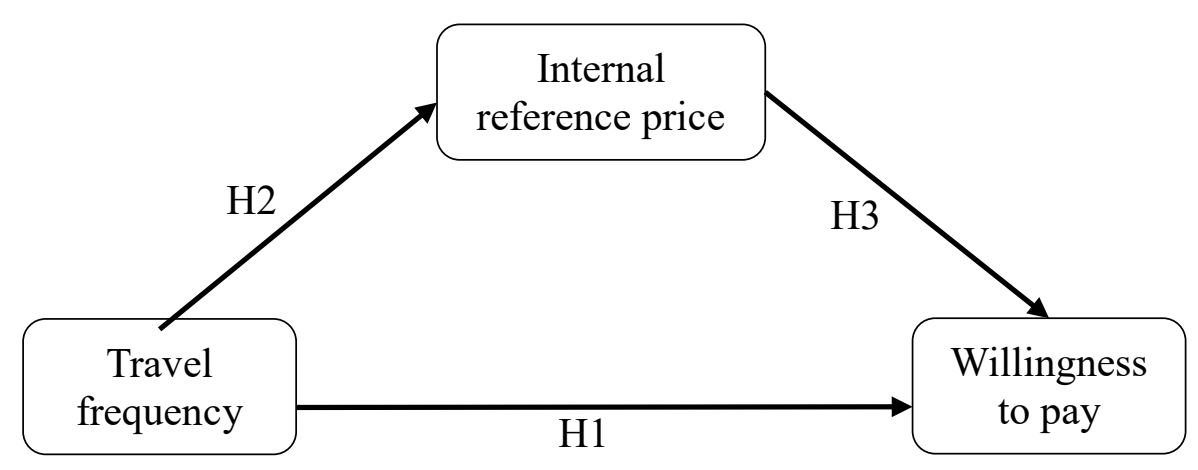


Figure 2a. Effect of travel frequency on IRP

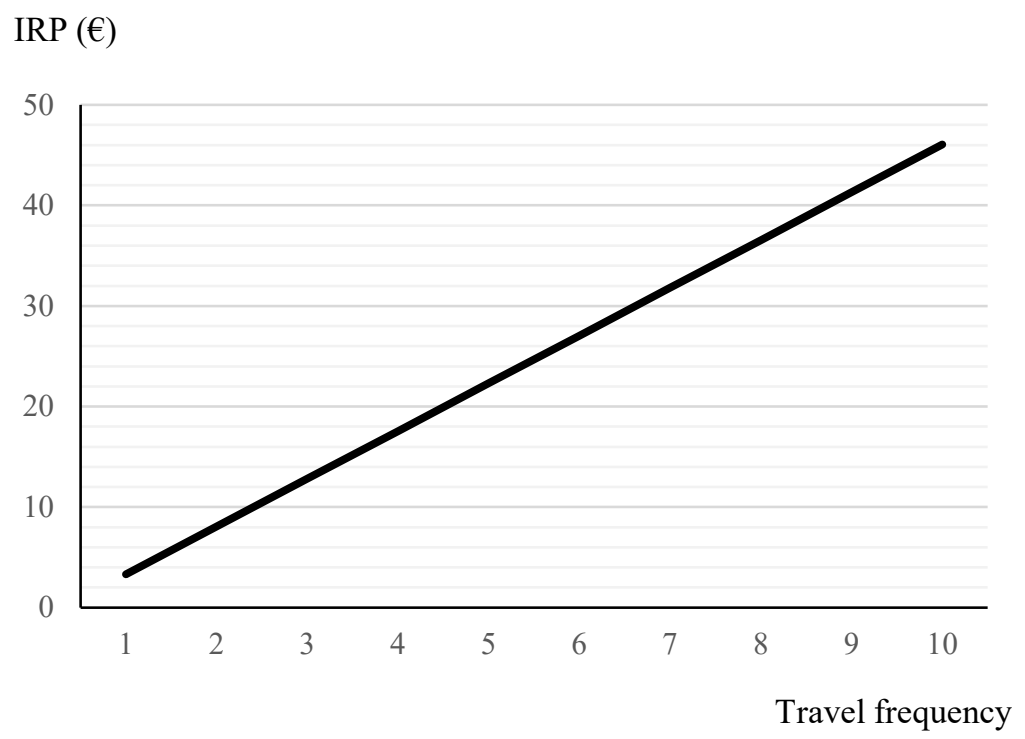

Figure $2 \mathrm{~b}$. Effect of IRP on willingness to pay

Willingness to

pay $(€)$

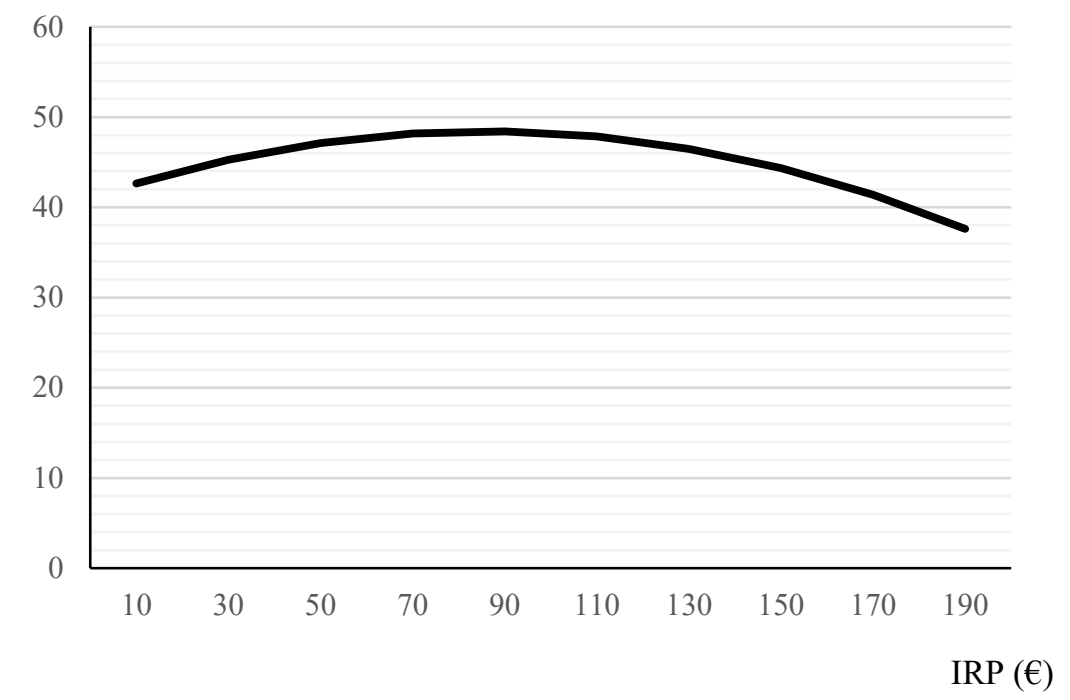


Figure 2c. Quadratic effect of travel frequency on willingness to pay

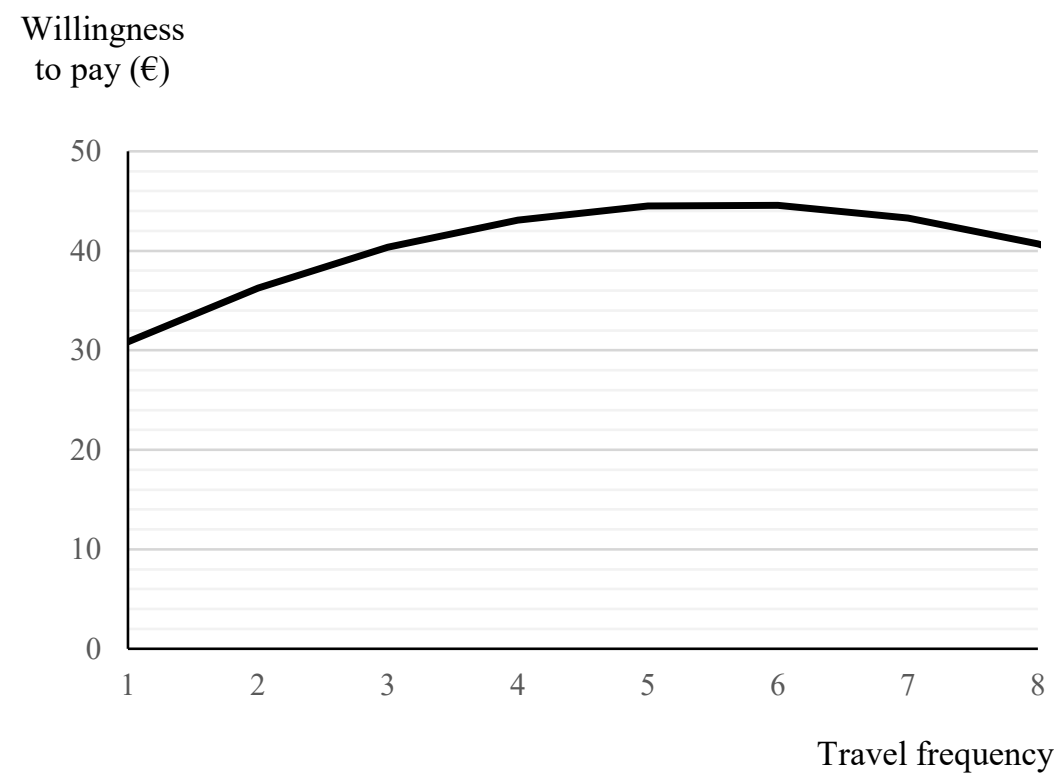


